\title{
Enchantment and non-human voices in the Sámi yoik
}

Enchantement et voix non humaines dans le yoik Sámi

\section{Stéphane Aubinet}

\section{(2) OpenEdition \\ 1 Journals}

Electronic version

URL: https://journals.openedition.org/clo/8663

DOI: $10.4000 /$ clo.8663

ISSN: 2266-1816

Publisher

INALCO

\section{Printed version}

Date of publication: 30 June 2020

Number of pages: $195-215$

ISBN: 978-2-85831-392-1

ISSN: 0396-891X

Electronic reference

Stéphane Aubinet, "Enchantment and non-human voices in the Sámi yoik", Cahiers de littérature orale [Online], 87 | 2020, Online since 16 September 2021, connection on 09 November 2022. URL: http:// journals.openedition.org/clo/8663; DOl: https://doi.org/10.4000/clo.8663

\section{(c) (i) \&}

Creative Commons - Attribution-NonCommercial 4.0 International - CC BY-NC 4.0 https://creativecommons.org/licenses/by-nc/4.0/ 


\title{
Enchantment and non-human voices in the Sámi yoik
}

\author{
Stéphane Aubinet \\ Department of Musicology, University of Oslo
}

\section{Introduction}

Through the word enchantment, I wish to capture a specific dimension of the practice of "yoiking;" an affective capacity in chants to make places resound with startling presences through vocal engagement.

The yoik is a vocal practice used by the Sámi people, whose traditional dwelling (Sápmi) is located in the northernmost part of Europe, covering an area similar in size to Germany and divided between four countries (Norway, Sweden, Finland, and Russia). ${ }^{1}$ A yoik is a melody with or without lyrics traditionally chanted $a$ cappella in everyday life, by women, men, and children alike.

Each melody is tied either to a person, an animal species, or a place; thus a Sámi community potentially has one yoik for the reindeer, one for the fox, one for each individual person, as well as yoiks for familiar rivers, mountains, towns, or other remarkable locations. Some animals may also have individual yoiks,

1. The existing literature on the yoik is considerable and covers a wide range of genres and approaches, such as ethnographic descriptions (Graff, 2016), musical analyses (Lüderwaldt, 1976), textual analyses (Gaski, 1999), semiotic analyses (Stockmann, 1991), cross-cultural investigations (Krumhansl et al., 2000), inquiries in musical therapy (Hämäläinen et al., 2018), postcolonial musicology (Hilder, 2013), reports by early visitors in Sápmi (Acerbi, 1832), essays by Sámi yoikers (Somby, 2007), and Sámi poetry (Valkeapää, 1994). 
typically reindeer or dogs. Those tied to an animal species may differ from one region to another and it is always possible to create new ones.

In all cases, the melody is intimately attached to what it evokes, so that it is common to hear in Sápmi that your yoik is you; or, that although people may sing about a person, people yoik the person (i.e. not "about"). ${ }^{2}$ To chant a yoik thus amounts to summoning the presence of the person, animal, or place evoked, as well as personal memories attached to it. This is generally done in privacy, when one is alone or with close relatives.

If a particular person has a yoik that describes her, this yoik is said to belong to her, regardless of who created it. Some yoikers even suggest that, if a personal yoik is beautiful, this is due to the beauty of the person evoked, not to the skill of its creator. Whether it evokes a person, a place, or an animal, the melody must indeed depict it with tones, as in a drawing, and express its character, appearance, sounds, or movements. One can never chant one's own yoik, as this would appear as a sign of vanity. As Ingor Ántte Áilu Gaup, a renowned yoiker from Kautokeino, once explained to me, chanting your own yoik would be like walking in the streets and yelling your own name (personal communication, July 2017).

The craft of yoiking can be learned like a mother tongue, by being immersed in what the Sámi scholar Nils Jernsletten calls a "yoik milieu"-i.e. a place where yoiking occurs in everyday life. Some yoikers state that they were able to yoik before they could talk (Graff, 2016). Others learn to yoik as adults, by participating in guided courses (as I did, as part of my investigation) or on their own, for example by trying to imitate recordings.

Importantly, all the Sámi do not yoik. In fact, this practice has long been considered in a negative light by some, especially among Laestadian religious circles in the North of Sápmi, either due to its supposed origins in pre-Christian shamanic ceremonies from the seventeenth and eighteenth century or its supposed relationship to alcohol consumption (Graff, 2016). In the past four centuries, it has also had to endure policies of national assimilation pursued by the Nordic countries until the second half of the twentieth century, during which signs of "Sáminess" were readily downgraded in favour of national culture.

Since then, the yoik has experienced a revival, starting at the turn of the 1970s at the instigation of artists like Nils-Aslak Valkeapää and bands like

2. According to many yoikers, yoiks are not songs. In North Sámi, yoiking is called juoigat and singing lávlut. Where necessary, I will rather use the term chant, more likely to evoke the circularity of yoiks, the fact that they are vocalised a cappella, and their incantatory quality. 
Tanabreddens Ungdom, who opened the way for various musical encounters today known as the "modern yoik" (Hilder, 2013), with performers of international renown like Mari Boine. It is today common to combine yoiks with rock, jazz, choral, or electronic music. Meanwhile, a new attention to the similarities between the yoik and other indigenous musical traditions-especially from the circumpolar North-has emerged, and numerous "modern yoikers" have used their expression as a means of enhancing the decolonisation of Sápmi or resisting discourses of modernity in a context of ecological disruption (Hilder, 2013; Ramnarine, 2009).

This paper will primarily focus on the "traditional" practice, the one performed a cappella, in everyday life, and away from studios and stages. Addressing the diversity of the "modern yoik" would require a study of its own. The focus is on pragmatic concerns: Why do some people yoik? How does it affect them? How does it affect the people, the animals, the places that they yoik? This emphasis on what the yoik can do (rather than on what it is) is derived from a recurring observation on the field. ${ }^{3}$ What struck me then was the way yoikers had no pretention at mastering their craft. To them, the yoik appeared as a particularly mysterious practice, not because it is esoteric-i.e. known only to an elite group-but because it is through participation that it reveals what it can do.

The practitioners I met were generally more inclined to describe it as a gift received from elsewhere (e.g. from nature, from the wind, from the earth, from their ancestors, from the underground spirits) than something that was "theirs." Most of the time, they only felt entitled to speak about their own experience, with little inclination for generalisation. It soon became clear that, no matter how many interviews I would conduct, I would not be able to get to an encompassing theory of the yoik: all I could hope to do was to navigate between situated discourses; countless variations of the same craft.

My research approach has consisted in taking these variations seriously, as bases for inquiries about what the yoik can be and what it can do. The idea of "taking seriously" must here be understood in the sense defined by the anthropologist Tim Ingold, namely as an attention "to the challenges [that others] present to our

3. My engagement with the yoik covers six years of research and eight months of fieldwork in Sápmi. Besides a review of the existing literature, I conducted fourteen recorded interviews with yoikers (most of which took place in Norwegian), participated in nine yoik courses (lasting from a few hours to five days), and presented my research in seven different Sámi institutions for feedback from various indigenous audiences (cf. Aubinet, 2020 for more information on the research approach adopted in my doctoral work). 
assumptions about the ways things are, the kind of world we inhabit, and how we relate to it" (Ingold, 2018, p. 15).

This paper is based on two encounters: (1) an anecdote about a yoiker who managed to frighten a couple of elk (Alces alces) by chanting the bear's melody and (2) a Sámi poem about the yoiking wind. These will address, in turn, the way humans can yoik to animals, the way non-humans can yoik to humans, and the way yoiking may affect the perception of a place. Focusing on these encounters opens the way for a reflection on the concept of enchantment, understood here as a condition where startling aspects of the environment are revealed through (human or non-human) chant.

Before turning to the first encounter, two points should be emphasised. Firstly, the observations gathered here are not necessarily meant to be representative of all yoik experiences. The yoik is a technique that presents countless variations and (like Spinoza's bodies) no one, either yoiker or scholar, has ever exhausted its possibilities. My aim is merely to capture something of the practice, one of its many folds, to take it seriously, and to explore some of the insights we can get from it.

Secondly, there is no Sámi term that exactly reflects the notion of "enchantment." ${ }^{4}$ This term is a proposition of my own, intended to complement the yoik with an additional conceptual layer. Ethnographically speaking, its merit lies in the description it affords, that is, in its capacity to point at one particular aspect of the practice.

\section{The fearful elk}

Although a clear majority of yoik performances take place in solitude or in human company, there appears to be a well-established tradition of yoiking to animalsone that, to the best of my knowledge, has never been written about by scholars.

Already in the eleventh century, the chronicler Adam von Bremen reported that the people living in the Norwegian Arctic used their vocalisations as a means of drawing the cetaceans from the sea to the shore (Bremen, 1876, p. 179). The term yoik was not in use then among writers, but the term murmure in Adam von

4. In North Sámi, "enchantment" could be translated as gierran, which is also the title of a record by the yoiker Wimme Saari. However, gierran lacks the etymological interest of its English counterpart. 
Bremen's text indicates that these may have been guttural chants reminiscent of contemporary yoiking. ${ }^{5}$

Nine hundred years after Adam von Bremen, the Sámi artist Nils-Aslak Valkeapää stressed the following:

The yoik is not merely music. Its functions are much wider than that. They include ways to social contact. To calm down the reindeer. To frighten the wolves. The yoik was never intended to be performed as art. Art requires public. The yoik was used to call up friends, even enemies. The land and the environment. Animals. The yoik was also a step to another world, which makes it religious. (Krumhansl et al., 2000, p. 18)

Reindeer herding is indeed a privileged environment for yoiking with animals. For example, it can enable the yoiker to approach a herd without scaring it (Graff, 2016, p. 27). Some yoikers, like Siri Päiviö (from the region of Arjeplog), even observed that the reindeer seems to understand the yoik and to appreciate it: "The reindeer like very much to listen [to the yoik]. I can directly see that they move their ears. They listen" (Skaltje, 2014, p. 40).

Along the course of my investigation, I encountered one particular anecdote that retained all my attention. It was told by Ánde Somby, as I visited him in his office at the University of Tromsø. Somby works as a researcher at the Faculty of Law and is also a famous yoiker, particularly known for his intense performances of the wolf's melody and other animal yoiks. The anecdote took place in 2014, as he was staying in a cabin in the Lofoten Islands, on the Norwegian coast, for a photography project in relation to the production of his record Yoiking with the Winged Ones. At some point, two elk arrived and interfered with the project. Somby tried yelling at them in order to scare them away but did not observe any response from the animals. Then he got another idea: "I immediately sent the dynamite: the bear's yoik" " (Emberland, 2014).

5. The original Latin text is: Tunc etiam potenti murmure verborum grandia cete maris in litora trabunt. Murmure traditionally refers to a murmur, a hum, or a growl. I thank the philologists Simon Midrez and Mathilde Puissant for helping me with this translation.

6. Ánde Somby here refers to the verse "Yoik has more power than dynamite" [no. Joik har storre kraft enn krutt], sung by Mattis Hætta and Sverre Kjelsberg at the 1980 edition of the Eurovision Song Contest. 
As soon as the yoik began, the elks' ears stood up in an attentive posture. After a few seconds, the animals turned around and walked away. ${ }^{7}$ As Ánde Somby told me,

I am able to replicate the order of the bear saying to the elk that "you don't come here, because here lives a bear!" And the elk then decides to respect that. Because we have been trying to shout with human voices, saying "get off the field!" But they don't respect that. (Personal communication, January 2015)

Unlike the anecdotes mentioned earlier, this one is remarkable in that Somby found an interesting response from elk not by chanting their yoik, but by yoiking a "third party" animal. This was not the first time that he managed to achieve this. On another occasion, he unwittingly traumatised a dog by yoiking the wolf during a concert. More intriguingly, he mentioned that when he once yoiked a grouse bird next to a hunting dog, the dog immediately took its pointing stance, indicating that it had spotted prey. According to him, "the ultimate applause you can get as a yoiker is when animals respond to you like this" (ibid.).

The reason why the elk's anecdote retained my attention is that it put me to the challenge of taking seriously the idea that a yoik brings something to presence. Somby's suggestion that animals can respond to this phenomenon was for me an invitation to consider it not merely as an artificial idea situated in a particular cultural context, but as an actual phenomenon observed through participation in a practice: there is indeed bearness in this voice.

This is where the notion of enchantment comes in. I want to start by taking the term in its most immediate, etymological sense: the bear is present in-the-chant, that is, it is made present within the vocalisation. Yoiking then appears as a craft of incantation, a term derived from the same Latin root. Etymology may be what led the ethnomusicologists Victor Stoichiță and Bernd Brabec de Mori to theorise enchantment as one possible "posture of listening" corresponding to a stance where "sounds seem to form an autonomous realm" (Stoichiță \& Brabec de Mori, $2017, \$ 31$ ) and "new beings [are brought] to social interaction" (ibid., \$ 51).

As they observed, this occurs in various instances, such as the perception of "tension" and "release" within the sounds of tonal music (ibid., \$35)-might

7. I did not directly witness the event. However, it was recorded in a video made public by the journal Nordlys in an online article (Emberland, 2014). I saw this video when I visited Ánde Somby in January 2015. Since then, it has been removed from the article's webpage. 
the way animals are brought to presence by yoiks constitute another example? Enchanted listening is in this regard opposed both to "indexical listening," a posture in which listeners pay attention to the source of a sonic stimulus, and to "structural listening," a posture relying on the abstraction of "relevant patterns from auditory data" (ibid., \$24), as supposedly occurs in language.

Useful as Brabec de Mori and Stoichițăs proposition may be for analytical or comparative purposes, I find that applying it to Somby's story would be rather reductive, due to the divide it implies between a listening subject and a sonic object (cf. Tim Ingold's critique in Dokic et al., 2018). ${ }^{8}$ In Alfred Gell's earlier definition of enchantment (cf. Gell, 1992), this fracture is constitutive of the phenomenon: a painting or a canoe-board "enchants" me because, while I am aware that it was created by a human agency, the technical process of its creation transcends my understanding. In his view, the feeling of enchantment stems from a fascination that can only be attributed to magic; it emerges when the object acquires some degree of autonomy from its creator in the eyes of the beholder and appears as a force of its own. This perspective is broadly consistent with Stoichiță and Brabec de Mori's proposition: there is, on the one hand, a yoiker who is indubitably human and, on the other hand, a sonic stimulus that the listener perceives as laden with bearness.

Trying to take the yoik seriously led me to another image. For if any yoiker is likely to agree that the bear is present "in the chant," it does not necessarily mean that it is contained in a melodic object, independently of its human performer; it rather appears that the animal comes out in the act of chanting. One way to expose what I mean here is to consider how some yoikers consider human interiority.

According to them, the bear and other animals are present not only in the outer terrain, but also inside humans. As Somby once put it: "We have an animal heritage that is deeply embedded into our genes, in any respect of the term 'gene.' [...] There is a wolf in me, and a raven, and a bear, and a lot of other animals" (personal communication, January 2015). In a book on Sámi shamanism, the yoiker and poet Ailo Gaup described these presences as "seeds:" "We all come into the world like bags of seeds. So, our job is to find out more about these

8. In his critique, Ingold argues that sound is not an object of perception that leaves its source behind in a "point to point" trajectory, but an ongoing phenomenon "swelling in its advance while simultaneously fading on the retreat." By emphasising "an affective correspondence" rather than a relation between agent and object, he proposes a redefinition of enchantment that better echoes with the propositions gathered in this paper (in Dokic et al., 2018, \$20-21). 
seeds and to water those we want to grow" (Gaup, 2007, p. 85). Another yoiker, Torgeir Vassvik, added the following when I met him in a pub in Oslo:

When you yoik, you do not yoik "about." You are what you yoik. So, if it is a wolf for instance, you make contact with your inner wolf. You have an inner image of what is a wolf, of what the wolf is, in itself, as a being. [...] The wolf is a power that is good to take forward, good to show off, it is a strength, it gives strength. We can connect to it and develop it in various directions. (personal communication, October 2016)

Thus, as I came to learn, the yoik is a technique that makes perceptible the idea of a continuity between the outer presences perceived in the environment and an inner ecology of beings. It is as if, by yoiking the bear, yoikers brought out something that was already present in them in the virtual mode, concealed within their inner folds. If, as I propose to do, this perspective is taken seriously, one must contemplate the possibility that the bear is in the yoiker as much as it is in the sound; that this very distinction already betrays the process that affects the person chanting; that the yoiker's breath is a zone of interpenetration where "inside" and "outside" merge into the presence of an animal. ${ }^{9}$ Using a formula by the ethnomusicologist Tina Ramnarine: during the vocalisation, "the yoiker, the yoik, and the yoiked are integrated" (Ramnarine, 2009, p. 205).

In this perspective, the enchantment observed in Somby's anecdote has little to do with transcendence (as it does in Gell's theory) or with blindness towards the sound's emitter (as it does in Stoichiță and Brabec de Mori's theory); the bear is immanently present in the chant and all the way to its source. Here, enchantment rather lies in the experience of encountering a startling "possible:" for the time of a vocalisation, Somby is revealed to be not just human, but also bear; reckless elk are revealed to be fearful creatures; and the yoik is revealed to be more powerful than one might assume (potenti murmure, as Adam von Bremen would put it).

This form of enchantment does not merely occur to "someone," but to "sometime" and "somewhere;" it affects an environment, it displaces the field of experience, it reconfigures perception, it enriches a situation with another

9. The words of the philosopher and botanist Emanuele Coccia here come to mind: "To blow, to breathe, indeed means making this experience: what contains us, the air, becomes contained in us and, conversely, what was contained in us becomes what contains us" (Coccia, 2016, p. 23). 
"possible" - if only temporarily. It is a vocally induced form of enhanced "animacy," as Tim Ingold defines it:

Animacy $[\ldots]$ is not a property of persons imaginatively projected onto the things with which they perceive themselves to be surrounded. Rather [...] it is the dynamic, transformative potential of the entire field of relations within which beings of all kinds, more or less person-like or thing-like, continually and reciprocally bring one another into existence. The animacy of the lifeworld, in short, is not the result of an infusion of spirit into substance, or of agency into materiality, but is rather ontologically prior to their differentiation. (Ingold, 2011, p. 68)

Right, but did the elk really understand that the yoik referred to a bear? I asked Somby this very question, to which he replied:

Well, I have no idea how an elk will think. But the interesting thing is that, before the video recording starts, the elk are deep in their grazing. Then, I come on this balcony and I start to yoik. And it was so fascinating, because they suddenly raise their heads, and then their ears come up, and they start to listen: "What's this?" And then they communicate with each other. And then they decide to run from the spot. (Personal communication, January 2015)

I was asking for an explanation. Instead of answering, he guided me back to the anecdote and its fascinating quality. Perhaps explanations would have been out of place. Indeed, even if it is taken seriously, Somby's story does not imply that all elk will flee every time the bear is yoiked in the future. I have it on good authority that they do not: I occasionally tried to yoik to elk and red deer in the forests around Oslo and, apart from an apparent curiosity on their part, I never observed any response that aroused the same fascination that Somby experienced. Of course, my yoiking skills are laughable compared to Somby's. The animals might have responded differently to him. Unless these søringer ${ }^{10}$ simply do not get the yoik as the northern elk do?

These explanatory hypotheses rather miss the point: what matters is that Somby's yoik has revealed the possibility of an interesting conversation with elk

10. "Southerners," as some Northern Norwegians call anyone living south of Nordland county. 
through the yoik, one that may or may not emerge next time he sees an elk, but one that remains, in all cases, possible.

\section{The blowing of the wind}

If yoiking to animals is a relatively common practice in Sápmi, it is uncertain whether animals themselves can yoik. However, other non-human entities are well known as yoikers, including the Gufihtar (or Ulda). These anthropomorphic spirits are said to live under the earth and to watch over the behaviour of humans when they are in the mountains. As the Sámi writer Johan Turi reported at the beginning of the twentieth century, "some Ulda are very skilful at yoiking, the Sámi often hear them, and they have learned the yoik from the Ulda" (Turi, 1910, p. 211).

However, my investigation led me to think that the non-human entity most likely to yoik is the wind. The yoikers I have met often seemed particularly attentive to its flow. In fact, a highly common way of creating new yoiks is to listen to its sound and to try to imitate it with a melody. However, as with the practice of yoiking to animals, it took a specific encounter, with a poem this time, before I started to think more attentively about this issue. The poem was written in North Sámi by the yoiker, writer, and painter Nils-Aslak Valkeapää in his book "Trekways of the Wind" (Ruoktu Váimmus).

to ask the wind why it blows why birds fly

why creeks flow

why the leaves fall from the trees why summer shy dark time

nothing is heard except the wind's song

the wind's song

beyond my gaze a string of visions

small fingers kneading the

mother's breast

life's first stumbling steps jearrat biekkas manin dat bossu manin girdet lottit manin jogat golget manin gahččet lasttat muorain manin geassi manin skábma

iige gullo earágo biegga šuvvá

biegga šuvvá

čalmmiid meaddel oainnuid ráidu unna suorpmažat láibume eatni čičciid eallima vuosttaš suoibu lávkkit 
the first teeth the first words into the world of adults adult life adult responsibilities nothing else to see and those who only travel among memories

on the lost moors of yesterday

to ask the wind why it blows

and hear

the wind's song

bring forth a yoik

a ringing yoik

courageously meet

eye after eye

Bring forth a yoik

take hold of a hand

make a heart

beat closer

Bring forth a yoik

From these blue tundras

I hear the story of life

winds rivers forests

yoik

and the tundra's winds yoiked

in the forests gorges valleys fjords vuosttaš bánit vuosttaš sánit

rávesolmmožin rahpaseapmi

olles agi olles fuolat oaidnit šat eará

ja sii geat eai šat vájalge earágo muittus

ivttáš máilmmi jávkan guolbaniin

jearrat biekkas manin dat bossu

ja gullat mot biegga šuvvá

biegga šuvvá

robttehit luodi

cuoddjilis luodi

roabkkadit geahčćat

čalmmis čalbmái

Robttehit luodi

ja dolet gieda gibtii

váimmu ravdda

lagabui coalkut

Robttehit luodi

dáid duoddariid alibis

gulan eallima muitalusa

biekkain jogain vumiin

juoigame

ja duoddariid biekkat juige

vumiin gorssain legiin vuonain

čuojai luonddu sinfoniia 
I suckled mother Sápmi’s breast

from the spring's silver vein

in the cradle of stones in the scree

the spring sun rocked opened

the buds on the slopes

the ice on the rivers

and the tundra's winds yoiked'.

(Valkeapää, 1994)
eadni-Sámi rattis njammen

ádjagiid silbasuonain

juovaid geadgegietkamis

gida beaivi vuohtui

rabai čuolmmaid urbbi

jogaid jienjain

ja duoddariid biekkat juige'.

(Valkeapää, 1985)

Analysing this poem in depth is beyond the scope of this paper and I will merely stress a few elements, starting with the expression "bring forth a yoik." It is translated from the North Sámi verb rohttet, literally "to pull into motion." Among yoikers, this verb refers to the act of holding a single tone for one or a few seconds before the melody actually starts. In Valkeapääs poem, it suggests a human yoiking gesture occurring within a wider narrative that starts and ends with the blowing of the wind, as if Valkeapää merely attempted to initiate a melodic motion within an environment that embraces him.

The ethnomusicologist Tina Ramnarine highlighted a similarly intriguing form of authorship in a one-hour long musical composition by Valkeapää (the "Bird Symphony"). This musical piece likewise starts with the sound of the wind and birds, introduces human yoiking (including Valkeapääs own yoik) after about thirty minutes, and then ends with birdsongs. "Valkeapaa," she notes, "sings himself in the Bird Symphony, vocalising his presence in his home environment." Relying on Steven Feld's acoustemology, she described the composition as revealing a "sonic sensibility" leading listeners to an "experiential truth," in particular the idea that "human musical expression is an aspect of a sonic ecosystem" (Ramnarine, 2009, pp. 202-205).

Attending to enchantment makes it possible to develop her proposition. For in Valkeapääs poem, the wind is not just an environment that embraces the yoiker; it seems to have a yoiking voice of its own. In the second part of the text, it is fully exposed as an enchanting force which, by blowing through the forests, gorges, valleys, and fjords, makes the "symphony of nature" resound. Like Somby revealing his bearness and the elks' fear with his voice, the wind exposes an unforeseen vitality in an environment that seemed just on the verge of emerging to life, depicted through various formulae evoking birth, infancy, and growth. 
This "enchantment of the land," as we could call it, is commonplace among yoikers. For example, Olov Sunna, a yoiker from the region of Bardu, reported the following: "even today, we yoik the mountain Čokču [...]. It is like a king to us, I think. It is a beautiful mountain and it can be seen from afar. And it becomes even more beautiful when it is yoiked" (Skaltje, 2014, p. 229, emphasis added). The Sámi scholar Elina Helander-Renvall likewise noted that "through songs, placenames, stories and memories, the lands become even more alive than they are thought to be" (Helander-Renvall, 2010, p. 48).

Valkeapää himself captured this form of enchantment in a painting, used as a cover picture for his record "The Magic of Sámi Yoik" (Valkeapää, 1998) and displaying a landscape vibrant with vitality. The mountains in the distance, the soil and birches are all revealed in unexpected shades. Such is perhaps the "magic" of the yoik. It puts the land in variation and brings forth to attention some of its “possibles:” presences, memories, affects.

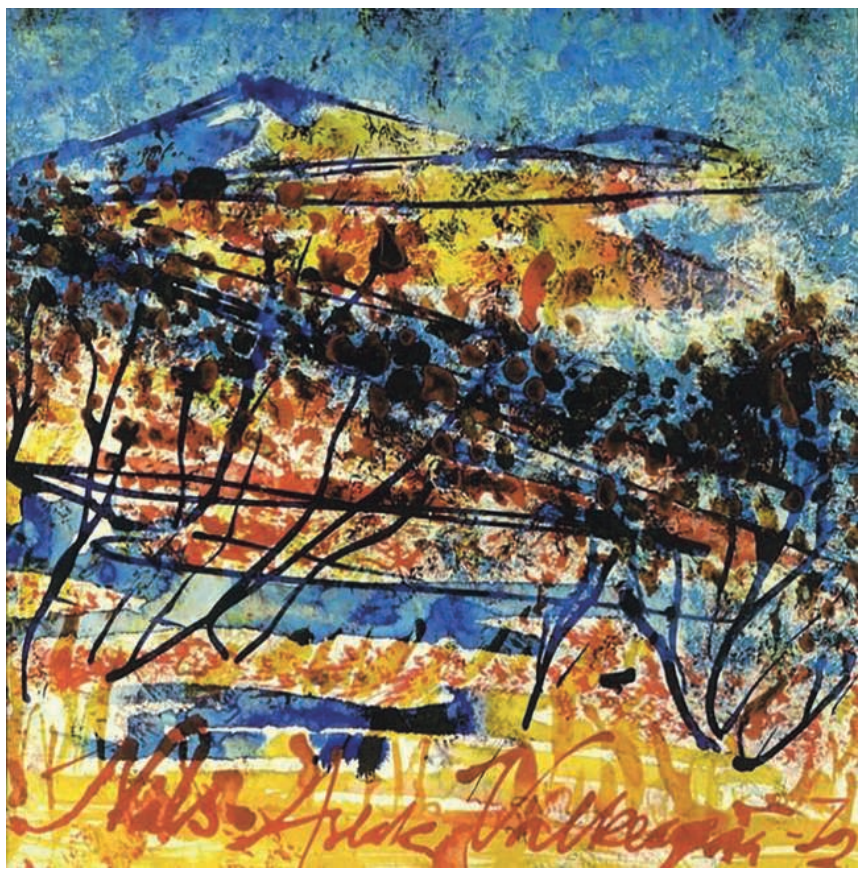

Illustration 1

Nils-Aslak Valkeapää, The Magic of Sámi Yoik

Picture included with the authorisation of Valkeapää's record label. 
Thus, there are doubtless metaphorical analogies to draw between winds and yoiks, which may remind the reader of Steven Feld's observations (this issue) on the relationship between waterfalls and Kaluli songs. In Sápmi and Bosavi, respectively, winds and waterfalls are at once a source of inspiration and a flow that runs in the land along song-like patterns. However, the analogy does not seem as institutionalised among the Sámi as it is among the Kaluli. When it came up during my conversations, the idea of yoiking winds appeared more as a matter of personal experience than as a cultural assumption shared by everyone in the area. In particular, the relationship between winds and yoiks is (to the best of my knowledge) not linguistically established.

As a matter of fact, the ethnomusicologist Ola Graff has recently argued that the insistence, among the Sámi, on a correspondence between the yoik and the flows of "nature" (e.g. winds, rivers, waterfalls, seasons) might only date back to the 1970's and Valkeapää was perhaps one of its instigators. According to Graff, the analogy emerged in a context of decolonisation of Sápmi and allowed yoikers to draw a distinction between the circularity of yoiks, supposedly reflecting the circularity of "nature," and the linearity of European songs (Graff, 2018, pp. 79-81). Consequently, Graff defines the idea of circularity and connection to "nature" as a "metaphor" designed to shape the Sámi "modern identity" (ibid., p. 77) as more closely related to other indigenous traditions than to the dominant cultures of the Nordic countries (ibid., p. 80).

Insightful as Graff's proposition is, "taking seriously" Valkeapääs idea of yoiking winds brings us further than historical contextualisation does. As Tim Ingold once observed, "we don't care for others by treating them as objects of investigation, by assigning them to categories and contexts or by explaining them away. We care by bringing them into presence, so that they can converse with us, and we can learn from them" (Ingold, 2018). Pursuing the investigation beyond contextualisation is all the more important because, whether yoiking winds are a recent proposition or not, whether they have a political resonance or not, they are now frequently invoked by various yoikers as something that they actually encounter in their lives.

This does not mean that the wind yoiks all the time. It requires particular attention from people to do so; some form of enchantment has to come in. When I asked yoikers whether the wind yoiks, they usually avoided "yes or no" answers and instead shared anecdotes, for example about this one time when they heard a remarkable wind and stopped to listen or to yoik along. In this regard, the wind is reminiscent of the Gufibtar. As Elina Helander-Renvall observed in Sápmi, "the awareness of the existence of spirits does not mean that they are continuously in a person's mind or company. Many times people become reminded of their 
existence first when some troublesome events take place, and after having strange dreams or when unusual noises are heard" (Helander-Renvall, 2010, p. 49).

In this sense, Valkeapää's poem should perhaps not be approached as a metaphoric text, but as a metamorphic one, following an argument by the philosopher and magician David Abram. According to him, "indigenous myths" tend to be metamorphic in that they point to "a hidden aspect of this very palpable terrain," a land "crouched in readiness to become something else" (Abram, 2010, p. 296). In this case, the wind is "crouched in readiness to become" yoik and the land in readiness to become a symphony. The idea of yoiking winds, although it may work as a metaphor and serve strategies in building an indigenous identity in a particular historical context, may be, in a more sensuous sense, as metamorphic as Ánde Somby's experience of enacting bearness. ${ }^{11}$

In fact, what Somby experienced when yoiking the bear could itself be described as an "enchantment of the wind." I had not considered this point until I stumbled upon another reflection by David Abram. Abram was commenting on the skill of a man who could understand what he called "the dialects of trees," that is, he could identify their species by listening to the wind blowing through them. Surely, as Abram notes, we could deny that trees have "dialects" at all and argue that they are entirely passive in the process. Yet, buman speech, he contends, suffers the same observation: "we talk, after all, only by shaping the exhaled air that rushed into our lungs a moment earlier. Human speech, too, is really the wind moving through..." (ibid., p. 171).

In a way, if the wind arouses the land by blowing through it, so it does in humans by becoming breath. In the latter case, it may find a realm of "inner presences"-all the animals, valleys, rivers, people dwelling inside a person's "genes"-to resound with, an interior topography to wander in, one place at a time. We should perhaps consider human interiority as a "prism" through which the wind, like white light, displays a whole range of diverging colours.

Returning to Valkeapääs poem: "Nothing is heard," indeed, "but the wind's song."

You may ask it "why it blows, why birds fly, why creeks flow, why the leaves fall from the trees," but instead of giving an articulate answer, it is likely to behave like

11. As the anthropologist Eduardo Viveiros de Castro suggested, in an animist context, to metamorphose into an animal is not "to conceal a human essence beneath an animal appearance, but rather to activate the powers of a different body" (Viveiros de Castro, 2015, p. 177); in this case, to activate a bear from within. 
Somby when I asked him why his elk were afraid, and simply guide your attention back to the enchantment that is occurring: "The wind's song."

Even beyond the practice of yoiking, the Sámi tend to consider the wind as an element that humans cannot fully possess, understand, or control. Among Sámi herders, in particular, it plays a crucial role by guiding the reindeer. As the Sámi scholar Mikkel Nils Sara noted, herders "often speak of reindeer as biekka buorri, 'a good governed by the wind.' This means that full control is impossible even though you can have reasonable hope to succeed in watching the herd" (Sara, 2009, p. 172). Likewise, yoikers may participate in the wind's expressivity and "pull it into motion" (rohttet), but enchantment is beyond their control. ${ }^{12}$

Anne-Lise Varsi, a yoiker from the region of Tana, reported to me a situation where she was trying to find inspiration from the wind for a new melody, but the inspiration did not come,

We hear many delightful sounds in nature, like the wind whistling [she blows air for a few seconds]. Once I was at a festival with my [shamanic] drum. I stood and I tried to imitate the wind to create a yoik out of it. But this time, it did not work. I stood there and the yoik did not come. (Personal communication, May 2017)

Yet, the wind remains potentially inspiring, "crouched in readiness" to become yoik.

"Enchantment" is a manifestation of this readiness in experience; a metamorphosis accomplished through a chanting voice-a voice that can take various forms (human or non-human), but, like the reindeer, always remains biekka buorri. As such, it does not call for explanations, but for more attention.

\section{Conclusion: "musicalising places"}

In a recent reflection on birdsong, Vinciane Despret pointed to a highly common, but little investigated process occurring while listening to music:

12. The priest Hans Skanke (1679 - 1739) reported that the "old noaidi" (shamans) considered the air as a "divine entity" (Guddoms vasen) (Skanke, 1945, p. 245). Among the tales of Sámi magical crafts that European travellers wrote about in the past centuries, cases where the Sámi could inflect its flow, or "catch" it in knotted strings in order to sell it, were predominant (Storfjell, 2013). I have not met anyone claiming to have this sort of ability today. 
Have you ever travelled on a train with headphones on your ears? Have you ever felt, as I have often experienced, that the landscape could be "Bachian," "Tchaikovskyan," how music imprints itself, covers, affects what surrounds us at that moment? Is it not so that an accordion in the metro changes not only the mood, but the very perception of things? (Despret, 2019, p. 123)

This is probably a fair approximation of enchantment as it occurs in the yoik, one that should be familiar to most readers. Through chants, the land is invited to display some of its hidden layers and reveal itself as more (more beautiful, more scary, more lively). Yet, this "musicalisation of a place," as Despret calls it, is not automatic. It does not systematically produce something interesting, and remains dependent on things partly beyond human control, such as our inner depths, the attention of animals, or the flows of the wind.

By using such a widely used term as "enchantment," I have no pretention to disqualify earlier definitions of the term nor to provide a representative view of all yoiking experiences. In my experience, some yoikers do not particularly care about inner animals and yoiking winds; others track their apparitions with great attention. Evidently, both the yoik and enchantment have many diverging nuances and the one proposed in these pages is but one variation that emerged thanks to two encounters - an anecdote and a poem — that had, for me, a quality that I am tempted to call "enchanting."

\section{References}

Abram David, 2010, Becoming Animal. An Earthly Cosmology, Vintage Books, New York, 336 p.

Acerbi Giuseppe, 1832, Viaggio al Capo-Nord fatto l'anno 1799 dal Sig. Cavaliere Giuseppe Acerbi [Travels to the North Cape accomplished in 1799 by Mr. Cavaliere Giuseppe Acerbi], Presso l'Editore Lorenzo Sonzogno, Milano, $312 \mathrm{p}$.

Aubinet Stéphane, 2020, The Craft of Yoiking: Philosophical variations on Sámi Chants, PhD thesis, University of Oslo, $441 \mathrm{p}$.

BREMEN Adam von, 1876, Scriptores Rerum Germanicum in usum scholarum ex monumentis germaniae historicis recusi [Germanic historians, for the use 
of students and based on germanic historical sources], Impensis Bibliopolii Hahniani; Hannoverae, 152 p.

Coccia Emanuele, 2016, La Vie des plantes. Une métaphysique du mélange, Payot et Rivages, Paris, $192 \mathrm{p}$.

Despret Vinciane, 2019, Habiter en Oiseau, Actes Sud, Arles, 208 p.

Dokic Jérôme, Hatten Robert S., Ingold Tim, Kreutzer Michel \& Tolbert Elizabeth, 2018, "Comments on 'Postures of listening' by Victor A. Stoichita and Bernd Brabec de Mori” in Terrain, http://journals. openedition.org/terrain/17547.

Emberland Torkil, 2014, "Her beviser Ánde Somby at joik har større kraft enn krutt [Ánde Somby proves that the yoik has more power than dynamite]" in Nordlys, 27 June 2014, https://www.nordlys.no/nyheter/ her-beviser-nde-at-joik-har-storre-kraft-enn-krutt/s/1-79-7446237.

Gaski Harald, 1999, “The Secretive Text: Yoik Lyrics as Literature and Tradition” in Nordlit, $\mathrm{n}^{\circ}$ 5, pp. 3-27.

Gaup Ailo, 2007, Inn i naturen. Utsyn fra Sjamansonen [Into nature. Perspective from the shamanic zone], Damm, Oslo, $145 \mathrm{p}$.

GeLL Alfred, 1992, "The Technology of Enchantment and the Enchantment of Technology" in Coote Jeremy \& Shelton Anthony (eds.), Anthropology, art and aesthetics, Clarendon Press, Oxford, pp. 40-63.

Graff Ola, 2016, Joikeforbudet $i$ Kautokeino [The prohibition of yoik in Kautokeino], Davvi Girji, Karasjok, 197 p.

GRAFF Ola, 2018, ”Joik er som en sirkel! Realitet eller ideology? [The yoik is like a circle! Reality or ideology?]" in Svensk tidskrift for musikforskning, n ${ }^{\circ} 100$, pp. 47-88.

Helander-Renvall Elina, 2010, "Animism, Personhood and the Nature of Reality: Sami Perspectives" in Polar Record, n 46(1), pp. 44-56. 
Hilder Thomas, 2013, Sámi Musical Performance and the Politics of Indigeneity in Northern Europe, Rowman and Littlefield, Lanham, 262 p.

Hämäläınen Soile Päivikki, Musial Frauke, Salamonsen Anita, Graff Ola \& Olsen Torjer Andreas, 2018, "Sami yoik, Sami history, Sami health: A narrative review" in International Journal of Circumpolar Health, $\mathrm{n}^{\circ} 77(1), 1454784$.

Ingold Tim, 2011, Being Alive. Essays on Movement, Knowledge and Description, Routledge, London, 288 p.

Ingold Tim, 2018, Anthropology: Why it Matters, Polity, Cambridge, 140 p.

Krumhansl Carol, Toivanen Pekka, Eerola Tuomas, Toiviainen Petri, Järvinen Topi \& Louhivuori Jukka, 2000, "Crosscultural Music Cognition: Cognitive Methodology Applied to North Sami yoik" in Cognition, no 76, pp. 13-58.

LÜDERWALDT Andreas, 1976, Joiken aus Norwegen: Studien zur Charakteristik und gesellschaftlichen Bedeutung des lappischen Gesanges [Yoiks from Norway: A Study on the Characteristics and Social Significance of Lappish Songs], Übersee-Museum Bremen, Bremen, 344 p.

Ramnarine Tina, 2009, “Acoustemology, Indigeneity, and Joik in Valkeapää's Symphonic Activism: Views from Europe's Arctic Fringes for Environmental Ethnomusicology" in Ethnomusicology, n 53(2), pp. 187-217.

SARA Mikkel Nils, 2009, "Siida and Traditional Sámi Reindeer Herding Knowledge" in The Northern Review, n' 30, pp. 153-178.

Skaltje Maj Lis, 2014, Minsta lilla liv har sin jojk [The smallest of lives has its yoik], DAT, Kautokeino, 303 p.

Skanke Hans, 1945, "Epitomes Historiæ Missionis Lapponicæ. Pars Prima. Anlangende de Nordske Lappers Hedendom og Superstitioner [Summary of the history of the Lappish mission. First part. Concerning the paganism and superstitions of the Nordic Lapps]" in Nordlands og Troms Finner i Eldre Håndskrifter, Brøggers Boktrykkeri, Oslo, pp. 175-224. 
Soмву Ánde, 2007, Joik and the Theory of Knowledge, http://alkman1.blogspot. no/2007/07/joik-and-theory-of-knowledge.html.

Stockmann Doris, 1991, "Symbolism in Sami Music" in Yosiniko Tokumaru et al. (eds.) Tradition and its Future in Music. Report of SIMS 1990 Osaka, Mita Press, Tokyo, pp. 263-274.

SToichiță Victor A. \& Brabec de Mori Bernd, 2017, "Postures of Listening. An Ontology of Sonic Percepts from an Anthropological Perspective” in Terrain, Symposia and Debates, http://terrain.revues.org/16418.

Storfjell Troy, 2013, "The Ambivalence of the Wild: Figuring the Sami in Pre-Colonial and Colonial Discourse to the Eighteenth Century" in Kajsa Andersson (ed.), L'Image du Sápmi, vol. 2, Humanistica Oerebroensia, Örebro, pp. 112-147.

Turi Johan, 1910, Muitalus sámiid birra - En bog om lappernes liv [An Account of the Sámi], Græbes Bogtrykkeri, Copenhagen, 152 p.

VAlkeApäÄ Nils-Aslak, 1985, Ruoktu Váimmus [Trekways of the Wind], DAT, Kautokeino, 322 p.

VAlkeapä̈̈ Nils-Aslak, 1994, Trekways of the Wind, DAT, Kautokeino, 328 p.

Valkeapä̈̈ Nils-Aslak, 1998, The Magic of Sámi Yoik, Finlandia Records.

Viveiros de Castro Eduardo, 2015, The Relative Native. Essays on Indigenous Conceptual Worlds, HAU Books, Chicago, 366 p.

Abstract: The yoik is a vocal technique used by the Sámi people in the northernmost part of Europe. It consists in short circular melodies chanted a cappella and intended to make a person, an animal, or a place present. In the view of many "yoikers," it is a gift received from the environment that you learn through participation and experimentation. This paper uses the concept "enchantment" as a conceptual bias to comment on two encounters: an anecdote about a yoiker who managed to frighten a couple of elk by chanting the bear's melody and a Sámi poem about the yoiking wind. These encounters address, in turn, the way humans can yoik to animals and the way non-humans can yoik to humans, displaying in both cases how chants may affect the perception of a place. 
Keywords: Sámi, singing, environment, territory, nature/culture, human-animal relations, pragmatism.

\section{Enchantement et voix non humaines dans le yoik Sámi}

Résumé : Le yoik est une technique vocale utilisés par les Sámi, dans la partie la plus septentrionale de l'Europe. Elle consiste à chanter des mélodies circulaires a cappella destinées à rendre présent une personne, un animal ou un lieu. D'après de nombreux «yoikeurs », il s'agit d'un don reçu de l'environnement que l'on apprend à connaître à travers la participation et l'expérimentation. Cet article utilise le concept «enchantement » comme un biais conceptuel afin de commenter deux rencontres: une anecdote à propos d'un yoikeur qui parvint à effrayer des élans en chantant la mélodie de l'ours et un poème Sámi à propos des yoiks vocalisés par le vent. Ces rencontres abordent, respectivement, la manière dont les humains peuvent yoiker aux animaux et celle dont les non-bumains peuvent yoiker aux humains, illustrant dans les deux cas comment le chant peut affecter la perception d'un lieu.

Mots-clefs : Sámi, chant, environnement, territoire, nature/culture, relations bumain-animal, pragmatisme.

\section{Notes sur l'auteur}

Stéphane Aubinet a travaillé sur le chant chez les Sámi de Norvège, les danses traditionnelles en Europe et la pratique des berceuses. Sa recherche aborde les divergences entre chant et écriture et le rapport au temps et aux non-humains dans l'expérience musicale. 